\title{
Dating a near eastern desert hunting trap (kite) using rock surface luminescence dating
}

al Khasawneh, Sahar; Murray, Andrew Sean; Thomsen, Kristina Jørkov; AbuAzizeh, Wael; Tarawneh, Mohammad

Published in:
Archaeological and Anthropological Sciences

Link to article, DOI:

$10.1007 / \mathrm{s} 12520-018-0661-3$

Publication date:

2019

Document Version

Peer reviewed version

Link back to DTU Orbit

Citation $(A P A)$ :

al Khasawneh, S., Murray, A. S., Thomsen, K. J., AbuAzizeh, W., \& Tarawneh, M. (2019). Dating a near eastern desert hunting trap (kite) using rock surface luminescence dating. Archaeological and Anthropological Sciences, 11(5), 2109-2119. https://doi.org/10.1007/s12520-018-0661-3

\section{General rights}

Copyright and moral rights for the publications made accessible in the public portal are retained by the authors and/or other copyright owners and it is a condition of accessing publications that users recognise and abide by the legal requirements associated with these rights.

- Users may download and print one copy of any publication from the public portal for the purpose of private study or research.

- You may not further distribute the material or use it for any profit-making activity or commercial gain

- You may freely distribute the URL identifying the publication in the public portal 


\title{
Dating a Near Eastern desert hunting trap (kite) using rock surface luminescence dating
}

Sahar al Khasawneh ${ }^{1}$, Andrew Murray ${ }^{2}$, Kristina Thomsen ${ }^{3}$, Wael AbuAzizeh ${ }^{4}$, Mohammad Tarawneh $^{5}$

\author{
${ }^{1}$ Faculty of Archaeology and Anthropology, Yarmouk University, Irbid, Jordan. \\ ${ }^{2}$ Nordic Laboratory for Luminescence Dating, department of Geoscience, Aarhus University, Roskilde, \\ Denmark. \\ ${ }^{3}$ Centre for Nuclear Technologies, Technical University of Denmark, DTU Ris $\emptyset$ Campus, Roskilde, Denmark. \\ ${ }^{4}$ Maison de l'Orient et de la Méditerranée, Archéorient, Paris, France. \\ ${ }^{5}$ AlHussein Bin Talal University, Petra, Jordan.
}

\begin{abstract}
This study reports the first radiometric dating applied to kite stone structure in Jordan using rock surface luminescence dating to three rock samples collected from the Jibal al-Gadiwiyt kite structure in the south east of Jordan. The sampling location, part of the kite enclosure, is in the form of a $125 \mathrm{~cm}$ deep hole lined with long slabs at the base and with stacked cobbles above. The pit had been back-filled by natural sediment deposition after abandonment. Three rock samples were collected from the site, and three sediment samples were taken in close association with two of the rocks. Using quartz fast- component dominated OSL signals, it proved possible to define a rock burial age of $\sim 10 \mathrm{ka}$ by examining the profile of luminescence with depth into the rock surfaces. Various light exposure events (including the most recent following archaeological excavation) could also be identified. The direct radiometric dating of this kite argues for a construction $\sim 10 \mathrm{ka}$ ago, with no evidence for use beyond $\sim 1$ ka after building.
\end{abstract}

\section{Introduction}

\subsection{Desert kites}

Desert kites are stone structures found throughout the Middle East and central Asia; they were first described in 1927 by Royal Air Force (RAF) pilots flying over the eastern Jordanian desert and the name is derived from their resemblance to the child's toy when viewed from the air (Rees, 1929) (Figure 1). Although recent studies have identified various forms and structures, in general they consist of two long low stone-walls, known as guiding walls, in a funnel-like shape converging into some sort of enclosure where the walls meet. At the corners of the enclosure, smaller cells or compartments called "blinds, hides" were often erected in the form of 3 to $5 \mathrm{~m}$ wide stone circles (Figure 1). Some kites have well over a dozen of such smaller circles (Kempe \& AlMalabeh, 2010).

Many functions have been proposed for these structures, but the most widely accepted hypothesis is that they were used to hunt wild animals, particularly gazelles - G. subgutturosa or goitered gazelle - (Maitland, 1927; Fowden, 1999; Holzer et al. 2010; Bar-Oz et al. 2011; Bar-Oz \& Nadel, 2013; Zeder et al. 2013). It is suggested that wild gazelle herds were chased into the funnel created by the outer walls and then herded into the end 
enclosures for capture or slaughter. The small cells or compartments have been interpreted as "hides" from hypothesis (Harding, 1954; Hoyland, 2001; MacDonald, 2005; Betts \& Helms, 1987). The tops of the funnel walls are often no more than $30 \mathrm{~cm}$ above the desert floor, and in many cases, there is no evidence that the walls were ever more than a single layer of stones high (Figure 1).

Recent investigations have significantly increased the number of known kite structures in the Near East, Egypt and Iraq, and high-resolution satellite images have been used to identify kites in Yemen and throughout Central Asia (e.g. Kazakhstan and Ozbakistan; Barge \& Brochier, 2011); of the 4616 structures so far identified, the largest group (1123) is found in Jordan (globalkite.fr) (Kempe \& Al-Malabeh, 2012, Kennedy \& Bishop, M. 2011). But despite the ubiquity of these sites, and the considerable investment of labour that must have been involved in their construction, almost nothing is known about the period(s) in which they were constructed and/or used. Some (Betts 1998; Helms \& Betts, 1987) speculate that they were constructed in the Levant's Neolithic period, others hypothesize that they were built early but kept in use for centuries; based on descriptions in traveller's journals some may even have been in use up until the late nineteenth century (Burckhardt, 1831; Wright, 1895, Musil, 1928). However, these hypotheses depend on only a very few chronological studies (Hozler et al. 2011; Betts, 1998; van Berg et al. 2004) and on comparative archaeological studies of kites and nearby sites. Unfortunately, there is an almost complete absence of the organic matter needed for radiocarbon dating and there are very few archaeological finds associated with locally- known relative chronologies. As a result, there is no robust chronological framework for the construction or period of use of any of these numerous, widespread, and presumably important, structures.

\subsection{Rock surface dating}

Luminescence dating, and rock surface dating in particular, offers a solution to this problem of dating kites. Rock surface dating is based on ability of the luminescence signal in solid rock matrices to be reset to varying degrees as a function of depth into the rock surface as a result of light penetration into the rock during daylight exposure. This resetting is followed by signal build-up after the rock is again shielded from light (e.g. by burial or megalith construction). The resetting of the signal occurs because charge is released at different rates at different depths, as described in Equation 1 (based on Sohbati et al. 2011):

$$
E(x)=\overline{\sigma \varphi_{\mathrm{o}}} e^{-\mu x} \quad \ldots \ldots \ldots \ldots \ldots \text { Equation } 1
$$

where $\mathrm{E}(\mathrm{x})$ is the trap emptying rate at depth $\mathrm{x}$ into the rock $(\mathrm{cm}), \overline{\sigma \varphi_{\mathrm{o}}}$ is the trap-emptying rate at the surface $\left(\mathrm{s}^{-}\right.$ $\left.{ }^{1}\right)$ and $\mu$ is the light attenuation coefficient $\left(\mathrm{cm}^{-1}\right)$. Assuming the latent luminescence $\mathrm{L}(x, t)$ is directly proportional to the trapped charge concentration $\mathrm{n}(x, t)$ at time $\mathrm{t}$ in seconds; then at time exposure $\mathrm{t}_{\mathrm{e}}$ the residual latent luminescence at depth $\mathrm{x}$ is given by (Sohbati et al. 2011):

$$
L(x)=\mathrm{L}_{0} \mathrm{e}^{-\mathrm{E}(x) \mathrm{t}_{\mathrm{e}}}=\mathrm{L}_{0} \mathrm{e}^{-\overline{\sigma \varphi} \overline{\mathrm{t}} \mathrm{e}} e^{-\mu x}
$$

Equation 2

where $\mathrm{L}_{0}$ is the initial latent luminescence. This model was later expanded by Freiesleben et al. (2015) to describe the cumulative effects of several events of signal resetting and build-up as result of a sequence of daylight exposures and burials (see Table 2). 


\section{Site description}

Our study is centred on the Jibal al-Gadiwiyt (JGHD02) kite located in the south east of Jordan, located about $70 \mathrm{~km}$ to the south-east of Al-Jafr (Abu-Azizeh \& Tarawneh, 2015). It is composed of two long low stone structure walls converging at the western end and open into an irregular star-shaped polygon enclosure (Figure 1). An excavation of the site in 2014 began to uncover the structure from the west side (Trench 1). This excavation revealed that the circular structure represented the top of a filled pit of depth $\sim 1.3 \mathrm{~m}$ (Figure $2 \mathrm{a}$ ). The pit is lined with long stones sitting on the inner ground surface of the pit, most of which reach to within $\sim 30 \mathrm{~cm}$ of the surface. Small cobbles are then stacked in layers above this lining until they reach the ground surface (Figure 2b) (Abu-Azizeh \& Tarawneh, 2015).

The pit appears to have been back-filled over time with several sediment layers. The lowest layer appears to have been washed in, but this is overlain by thick blocky, presumably wind-blown, sandy layers (without any small stones) which curve upwards towards the walls of the pit (Figure 2c and Figure 3). Two thin, possibly water-lain, units containing gravels and pebbles are intercalated in the Aeolian sediments. At the right side of the pit section a number of cobbles and rocks appear to have fallen or been pushed into the pit to form a rampshaped slope that reaches to the present surface (Figure 2c and Figure 3). These large clasts do not appear to originate from the wall of the pit, and they sit on top of the lowest (water-lain) sediment layer of the section. It is very unlikely that these large clasts could have been moved by water.

There is no evidence of when the kite JGHD02 was built, or for how long it was in use. However, the presence of nomadic camp site $<400 \mathrm{~m}$ to the southeast has led to the suggestion that the two sites are related, and that kite was possibly used by the inhabitants of the camp site (Abu-Azizeh \& Tarawneh, 2015). Dating the campsite itself is only indirect; one radiocarbon date from a similar nearby site suggests that it could be attributed to the beginning of the $4^{\text {th }}$ millennium BCE (Late Chalcolithic/Early Bronze Age) (Abu-Azizeh, 2013).

\section{Sample preparation and measurement facilities}

\subsection{Rock samples}

The primary target sample (JGHD02/E24; Figure 2b and 3) is part of the pit construction, it is a single flat rock used to line the inner wall of the pit. The rock is $\sim 50 \mathrm{~cm}$ high, $\sim 25 \mathrm{~cm}$ wide and $\sim 10 \mathrm{~cm}$ thick. As a result of excavation, the surface $l$, facing into the pit, had been exposed to daylight for 5 months prior to sampling. The surface $O$, facing away from the pit, and presumably buried at the time of construction of the pit, remained buried at the time of sampling. The rock was sub-sampled in the field using hammer and chisel to give a piece of full thickness and width, but only $\sim 20 \mathrm{~cm}$ high; this sub-sample was wrapped in black plastic sheet for return to the laboratory.

Two other rocks were sampled from within the back-fill (see Figures 2c and Figure 3). One rounded cobble (JGHD02/E02) lay directly on the pit floor; it is $\sim 15 \mathrm{~cm}$ on its longest axis, and $\sim 10 \mathrm{~cm}$ on its shortest. A further cobble $(\sim 10 \mathrm{~cm}$ by $\sim 6 \mathrm{~cm}$; JGHD02/E35) was collected from the bottom of the rock fall on the right side of the section; this cobble was recovered after half had been exposed by excavation, the exposed/unexposed line was marked on the surface. For every rock sample, sediments that are adjacent to the rock surfaces were also collected for environmental dose rate measurements, in case of Rock E24, only the upper part was sampled for 
measurements, and sediment from the section that is adjacent to it was taken for the environmental radioactivity. Unfortunately, some of our samples were lost during transit, and we could not recover the sediment sample that is near outward surface of rock E24, so we substitute this sample with the nearest possible sample for the rock (Figure 3).

All rock samples were taken into reduced light condition, covered directly with black bags to prevent any light exposure.

In the laboratory, solid cores $(\sim 10 \mathrm{~mm}$ in diameter, $\sim 20-50 \mathrm{~mm}$ long) were drilled from the surfaces of the rocks using a water-cooled diamond-tipped core drill. These cores were then sliced using a diamond wafering saw (blade thickness $300 \mu \mathrm{m}$ ) into disks of thickness $\sim 1 \mathrm{~mm}$; the depths of the midpoint of each slice were tracked relative to the original surface.

Using a simplified XRF analysis (Kook et al. 2011) it became clear that these rocks are composed of quartz-rich sandstones- there was some carbonate, but any feldspar was below the detection limit. By treating the slices first with $10 \% \mathrm{HCl}$ and then $40 \% \mathrm{HF}$ full disaggregation of the quartz grains was possible, without any mechanical treatment. (Note that if $\mathrm{HCl}$ was not used, the discs were only slightly attacked by the HF.) After disaggregation, the grain size fraction 180-250 $\mu \mathrm{m}$ was separated for OSL measurement, and the quartz grains were mounted on $9.8 \mathrm{~mm}$ diameter stainless steel disks using silicone oil as an adhesive.

\subsection{Luminescence measurements}

Luminescence measurements employed by an automated Ris $\varnothing$ TL/OSL-DA20 luminescence reader (BøtterJensen et al. 2010) equipped with a calibrated ${ }^{90} \mathrm{Sr} /{ }^{90} \mathrm{Y}$ beta source delivering $\sim 0.15 \mathrm{~Gy} / \mathrm{s}$, blue LEDs (470nm, $\sim 80 \mathrm{~mW} / \mathrm{cm}^{2}$ ) and infrared (IR) LEDs (870nm, up to $\sim 135 \mathrm{~mW} / \mathrm{cm}^{2}$ ). OSL signals were detected through $7.5 \mathrm{~mm}$ of UV Hoya U-340 filter. Quartz dose estimates are based on a SAR protocol (Murray \& Wintle, 2000), with signals derived from the first $0.4 \mathrm{~s}$ less a background from the following $0.4 \mathrm{~s}$.

\subsection{Dose rate}

Bulk samples of sediment and rocks were prepared for dose rate analysis by ashing at $500^{\circ} \mathrm{C}$ to remove any organics, and then crushing, homogenizing and casting in a fixed cup- shaped geometry for gamma spectrometry analysis (Murray et al. 1987). The resulting radionuclide concentrations were converted to dry dose rates using data provided by Guérin et al. (2011). The. Water contents are based on measured field values. All water contents (expressed as \% of dry weight) radionuclide concentrations and resulting infinite matrix dose rates are summarized in (Table 1). Total beta and gamma dose rates inside each rock, at different depths, were calculated based on the principle of superposition (Aitken 1985, Appendix H), using the rock and the adjacent soils infinite matrix dose rates, taking into account the sediment water content (Table 1 and 4). assuming a quartz internal dose rate of $0.06 \pm 0.03 \mathrm{~Gy} / \mathrm{ka}$. a cosmic ray dose contributions $(0.22 \pm 0.02 \mathrm{~Gy} / \mathrm{ka}$ for the 3 rock samples, and are independent of depth into rock surfaces) are based on the calculations suggested by Prescott and Hutton (1994). 


\section{$4 \quad$ Luminescence characteristics}

The inset to Figure 4 shows typical blue-light stimulated luminescence from quartz grains from slices taken at $3 \mathrm{~mm}$ depth into the upper side of rock E24 and E35. The signal from calibration quartz (Hansen et al. 2015) is shown for comparison, and it can be seen that the natural signal is dominated by the fast component. Figure 4 also shows the dose response curve for the same aliquots, with the sensitivity-corrected natural luminescence interpolated onto the response curve to give the $\mathrm{D}_{\mathrm{e}}$.

The performance of SAR protocol was first examined using recycling ratios and recuperation values. The overall average recycling ratios are $0.998 \pm 0.013(n=140), 0.979 \pm 0.015(n=264)$, and $0.994 \pm 0.008(n=72)$ for grains from rock samples E02, E24 and E35, respectively. The average recuperation, expressed as a fraction of the natural luminescence is $2 \%(n=97)$ E02, 4\% $(n=264)$ E24 and 3\% $(n=72)$ E35. These results confirm that our SAR protocol is able to correct accurately for any sensitivity changes in the laboratory-regenerated SAR cycles in our samples.

We then undertook dose recovery tests on fresh aliquots of grains from the 3 rocks; these gave measured to given dose ratios of $1.058 \pm 0.014(\mathrm{n}=24), 1.09 \pm 0.07(\mathrm{n}=6)$ and $1.05 \pm 0.03(\mathrm{n}=6)$ for E24, E02 and E35 respectively; results for rock E24 are shown in Figure 5a. As a result of dose recovery measurement at different preheats (Figure 5b) and thermal transfer tests (data not shown) it was decided to use preheat/cut heat of $200 / 160^{\circ} \mathrm{C}$ for sample E02, $260 / 220^{\circ} \mathrm{C}$ for E24 and $220 / 180^{\circ} \mathrm{C}$ for E35

\section{Application of the rock surface model to the luminescence depth profile}

Figure $6(\mathrm{a}, \mathrm{b}$ and $\mathrm{c})$ shows the normalised OSL profile $\left(\mathrm{L}_{\mathrm{n}} / \mathrm{T}_{\mathrm{n}}\right)$ as a function of depth from the surface for samples E02, E24 and E35. It is clear from visual inspection that the surfaces of all samples had been exposed to sunlight prior the final burial event. The effect of the second daylight exposure (of about 5 months) of sample E24 after excavation is also obvious for surface $(I)$; the effect of a very recent light exposure is not present in the profiles from samples E35 and E02 because cores were drilled into that part of the surface that had remained covered by sediment after excavation. The profile from the bottom surface of E02 does not penetrate as far into the rock as that from the top surface, or as far as the profiles from the other 2 samples, and it seems likely that this surface received significantly less light exposure than the other surfaces before burial. Presumably this was because it was exposed to daylight for a shorter time.

To quantify these qualitative observations, we fit the data of Figure (6 a-c) with the model initially developed by Sohbati et al. (2011) and expanded by Freislaben et al. (2015).

\subsection{Fitting the model}

The equations described in Table 2 were fitted to the luminescence profiles from the three rocks samples. Equation $L_{2}(x)$ (describing a burial event after long time exposure) was used to fit the two surfaces of rocks E02 and E35 and Equation $L_{3}(x)$ (describing a second exposure) used to fit rock E24. We assume that the light attenuation factor $\mu$ is constant throughout each rock, and so we fit the two profiles from opposite sides simultaneously, assuming both $\mu$ and $\overline{\sigma \varphi_{0}}$ are shared parameters in the two fits. The constant $D_{o}$ was derived 
from relevant dose response curves determined using 12, 43 and 10 slices of samples E02, E24 and E35

The fitting results for the three rocks are shown as black solid lines in Figure 6a-c. The derived parameters are summarised in Table 3.

\subsection{Light intensity bleaching during daylight exposure $t_{\mathrm{e} 1}$}

Rock E02 (on floor of pit): The profile shapes immediately prior to final burial can be calculated from the fitted parameter values - these are shown as a dashed line (blue line) in Figure 6a. These fits confirm the qualitative conclusion above, that the downwards facing side only received limited light exposure (during $t_{e l}$ ) before final positioning, insufficient to fully reset even the surface $1 \mathrm{~mm}$ of the sample and the fitting is unable to resolve the subsequent burial time. The upper surface, on the other hand, clearly received (during $t_{e l}$ ) a much longer exposure; according to the model fit this was sufficient to reset the signal to a depth of $1.7 \mathrm{~mm}$ to $<3 \%$ of the luminescence signal acquired during subsequent burial (Table 4).

Rock E24 (standing rock in the wall of pit): The inward-facing surface (I) shows two exposures (Figure 6b); an earlier daylight exposure $\left(t_{e l}\right)$ occurred during the use of the kite in antiquity, and the more recent exposure $\left(t_{e 2}\right)$ known to have occurred after archaeological excavation. In contrast, the surface $(O)$ facing away from the pit (buried at the time of sampling) shows only one exposure event $t_{e l}$, which must have taken place before or during construction of the wall. As above, the parameter values have been used to predict the profile shapes that would have been present in antiquity, before burial. These curves are shown as dashed lines (blue line) in Figure $6 \mathrm{~b}$ and they can be compared to the total luminescence signals present after burial. On the outer-facing surface $(O)$, it appears that the surface was bleached to $<3 \%$ of the subsequent burial signal to a depth of $17 \mathrm{~mm}$, and on the inward surface $(I)$ to a depth of $8 \mathrm{~mm}$ (Table 4 ).

The effect of modern exposure partially erased the burial signal on the inward facing surface ( $l$ ). Using the fitted parameter values, the effect of recent bleaching of the burial signal has been calculated; of the well- bleached slices $(0$ to $8 \mathrm{~mm})$ only the two slices centred at depths 5.35 and $6.35 \mathrm{~mm}$ have lost $<10 \%$ of their burial signal.

Rock E35 (from pit back-fill): In this case, both surfaces each reflect only one exposure (Figure 6c); as discussed above it appears that at least the downward facing side received significant light exposure (during $t_{e l}$ ) before its final positioning in the pit. In the case of the upwards-facing side we cannot tell whether the light exposure occurred only before positioning, or whether there was further exposure after positioning, to give the total period of exposure of $t_{e l}$.

The parameter values were used to predict the profile shapes before burial in antiquity. These curves are shown as dashed lines (blue line) in Figure $6 \mathrm{c}$ and they can be compared to the total luminescence signals present after burial. It appears that the upward facing side was sufficiently well bleached to a depth of $3 \mathrm{~mm}$ to reset the signal to $<3 \%$ of the luminescence signal acquired during subsequent burial; in contrast, the downwards-facing side was reset to a depth of $7 \mathrm{~mm}$ (Table 4). 


\section{Burial Ages}

Burial ages were derived in two ways: (i) using the value of the parameter $\left(t_{b l} / D_{o}\right)$ from the fitting model and $D_{o}$ from the dose response curve for each side of the three rocks; (ii) Using the $D_{e}$ estimates derived directly from the SAR growth curve of each slice identified above as well-bleached before burial. All these ages are summarised in Table 5, calculated errors are based on random error added to 0.05 systematic error.

Rock E02: only data from the top surface of the rock was used to estimate a burial age. Using the parameters from the fitting $\left(t_{b l} / D_{o}\right)$ from the fitting and an average $D_{o}$ from dose response curves, the estimate age is $10.098 \pm 0.999 \mathrm{ka}$. Using the SAR dose estimates from individual slices gives an age of $9.1 \pm 0.7 \mathrm{ka}(\mathrm{n}=2)$.

Rock E24: the outward-facing surface ( $O$, covered at the time of sampling) was calculated above to have been well bleached to a depth of $16 \mathrm{~mm}$, and the sensitivity corrected luminescence is approximately constant to that depth, except for the first 2 surface slices. These increase slightly because of the increased beta dose rate from the more active surrounding sediment, but this contribution is poorly known compared to the well-known internal beta dose rate of the rock (mainly because the directly relevant sediment sample was lost in transport, and the sediment beta dose rate on this side of the rock is based on a sample taken $\sim 20 \mathrm{~cm}$ from the core locations). Fortunately, we can avoid this problem by simply ignoring the two surface slices. The age resulting from fitting (i.e. using an average $\mathrm{D}_{\mathrm{o}}$ ) is $8.9 \pm 0.6 \mathrm{ka}$, compared to that based on direct SAR dose estimates from individual slices (97-83 $\mathrm{mm}$ from the outward surface) of 8.6 $\pm 0.7 \mathrm{ka}(\mathrm{n}=15)$.

The profile from the inward surface is more complex because of the two exposures events ( $t_{e l}$ during the kite use and $t_{e 2}$ after archaeological excavation). Nevertheless, using the parameters from the fitting $\left(t_{b l} / D_{o}\right)$ and $D_{o}$ from

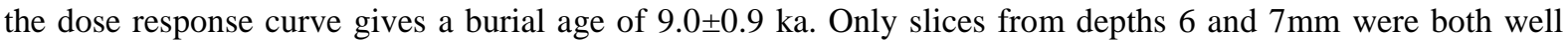
bleached in antiquity, and unaffected by modern bleaching after excavation. Using direct SAR dose estimates only from these slices gives an age of $9.7 \pm 1.2 \mathrm{ka}(\mathrm{n}=2)$.

Knowing that the second exposure time $t e_{2}$ of the inward surface is 5 months since the archaeological excavation $\left((4 \pm 1) \times 10^{-4} \mathrm{ka}\right.$, assuming an error of 0.02 of full exposure time), and by using the values of the fitting parameter, it is now possible to calculate the first exposure time of surface $I\left(t_{e 1}\right)$ which represent the duration of kite use. From equations $\mathrm{L}_{1}$ and $\mathrm{L}_{2}$, the de-trapping rate $\overline{\sigma \varphi_{0}}$ can now be calculated and $\mathrm{t}_{\mathrm{e} 1}$ is found to be $0.0035 \pm 0.0003 \mathrm{ka}$, which is very short use.

Rock E35: both surfaces of this rock seem to have a relatively simple history of exposure and burial; the upper surface was bleached to a depth of $3 \mathrm{~mm}$ before burial, and the lower to $7 \mathrm{~mm}$. Using the fitted values of $t_{b l} / D_{o}$, and an average $D_{o}$ from the dose response curves gives age of $8.8 \pm 0.5 \mathrm{ka}$ for the top surface and $10.7 \pm 0.5 \mathrm{ka}$ for the bottom surface. Using direct SAR dose estimates from the slices identified as well bleached gives ages of $10.48 \pm 1.07 \mathrm{ka}(\mathrm{n}=3$; top surface) and 12.6 $\pm 0.9 \mathrm{ka}(\mathrm{n}=6$; bottom surface).

\section{Discussion}

Rock E24 is clearly part of the construction and it is the only sample that must have been laid down at the time the pit structure (and presumably the rest of the kite) was built. This sample represents incontrovertible evidence of human activity; its position cannot be attributed to natural causes. This is in contrast to rock samples (E02 and E35), which could have been put in place by natural events after the pit was constructed. 
In what follows, we use the ages based on directly measured SAR doses for individual slices (see above). These ages do not include the assumption that all slices have the same $D_{0}$, and so are considered the more accurate.

The inward facing surface of Rock E24 was last buried 9.7 $\pm 1.2 \mathrm{ka}$ ago. In contrast, the outward-facing surface appears to have been buried only $8.6 \pm 0.7 \mathrm{ka}$. Both dose estimates are equally reliable, but $\sim 78 \%$ of the gamma dose rate to the outward-facing surface is based on a single sediment sample taken $\sim 20 \mathrm{~cm}$ from the core location, towards a lower corner of the vertical rock slab (because the original sediment sample was lost in transport). (In contrast, this sediment sample only contributes $15 \%$ to the total gamma dose rate to the surface layers on the inward-facing surface). Because of this unavoidable uncertainty in dose rate, we consider the age of the inward-facing surface to be the more reliable.

The top surfaces of Rock E02 and Rock E35 give burial ages of 9.8 $\pm 0.2 \mathrm{ka}$ and 10.8 $\pm 1.1 \mathrm{ka}$, respectively. These are indistinguishable from the age of the wall slab Rock E24, and suggest that the pit was certainly not maintained for more than a few hundred years after construction (Table 4). If the 'ramp' of large rocks on the right of the section shown in Figure 2c was put in place by human activity, (i.e. not by some extreme natural event) then it would appear that people did encounter the structure sometime after it fell out of use and may have deliberately altered it to prevent it acting as an animal trap.

\section{Conclusion}

The luminescence depth profiles for the rock samples examined from the Jibal al-Gadiwiyt kite contain surprisingly detailed information about burial and exposure history, and it proved possible to use the fitting parameters to calculate the depths to which the rocks were well bleached before deposition final burial. We suggest the ages derived by using $D_{e}$ estimate directly from using a SAR protocol directly on individual aliquots are more reliable than those derived from the fitting model parameter, because the model makes use of an average $D_{o}$ value for the entire profile, rather than the individual $D_{o}$ values appropriate to each aliquot. Based on the model prediction of bleaching depth, and the SAR dose estimates from the bleached layers, the burial age of our three rocks are $\sim 9.8 \pm 0.8 \mathrm{ka}(\mathrm{n}=28$, number of all well bleached layers in the three rocks).

There seems no doubt that the first instrumental ages from the Jibal al-Gadiwiyt kite suggest that construction took place $\sim 10,000$ years ago. This is considerably older than expected and puts the use of this site firmly in the Neolithic period, considerably older than the anticipated Late Chalcolithic/Early Bronze Age. Results also indicates that it is very likely that the kite use were for short period and more than 4 years for Jibal al-Gadiwiyt kite structure .

Megalithic structures are widely spread in the ancient landscape of Jordan, they exist in different forms, such as kites, linear, dolmens and wheel structures. Despite the variations in the form and function, the chronology of these structure has always been a debate among scholars because of the lack datable materials. However, these sites now are potentially datable using luminescence rock surface dating technique as seen in this case and previous studies in the region (Sohbati et al., 2015; al Khasawneh et al., 2018). 
Table 1: Radionuclides concentrations and infinite matrix dose rates for sediment samples and rock samples. gamma and beta dry dose were calculated by converting resulting radionuclide concentrations based on data provided by Guérin et al. (2011).

\begin{tabular}{|c|c|c|c|c|c|c|c|c|}
\hline Code & $\begin{array}{l}\text { Water } \\
\text { Content } \\
(\%)\end{array}$ & $\begin{array}{l}{ }^{238} \mathrm{U} \\
(\mathrm{Bq} / \mathrm{kg})\end{array}$ & $\begin{array}{l}{ }^{226} \mathrm{Ra} \\
(\mathrm{Bq} / \mathrm{kg})\end{array}$ & $\begin{array}{l}{ }^{232} \mathrm{Th} \\
(\mathrm{Bq} / \mathrm{kg})\end{array}$ & $\begin{array}{l}{ }^{40} \mathrm{~K} \\
(\mathrm{~Bq} / \mathrm{kg})\end{array}$ & Beta $(\mathrm{Gy} / \mathrm{ka})$ & $\begin{array}{l}\text { Gamma } \\
(\mathrm{Gy} / \mathrm{ka})\end{array}$ & $\begin{array}{l}\text { Total dose } \\
\text { rate }(\mathrm{Gy} / \mathrm{ka})\end{array}$ \\
\hline \multicolumn{9}{|c|}{ Sediments samples } \\
\hline BB641 & 0.82 & $11.5 \pm 16.8$ & $36.2 \pm 1.3$ & $8.1 \pm 1.2$ & $59 \pm 12$ & $0.81 \pm 0.04$ & $0.68 \pm 0.02$ & $1.70 \pm 0.06$ \\
\hline BB642 & 1.8 & $55.25 \pm 19.08$ & $82.3 \pm 1.6$ & $18.4 \pm 1.1$ & $107 \pm 15$ & $1.02 \pm 0.09$ & $0.87 \pm 0.07$ & $2.06 \pm 0.12$ \\
\hline BB687 & 1.6 & $123.9 \pm 15.4$ & $54.5 \pm 1.2$ & $19.22 \pm 1.1$ & $75.4 \pm 11.7$ & $0.87 \pm 0.03$ & $0.76 \pm 0.02$ & $1.83 \pm 0.06$ \\
\hline BB697 & 2.4 & $92.5 \pm 17.2$ & $99 \pm 2$ & $18.2 \pm 0.9$ & $55 \pm 12$ & $1.28 \pm 0.03$ & $1.11 \pm 0.03$ & $2.53 \pm 0.07$ \\
\hline \multicolumn{9}{|c|}{ Rock samples } \\
\hline E02 & 0.4 & $16 \pm 15$ & $20.9 \pm 1.1$ & $3.7 \pm 1.1$ & $0.0 \pm 12$ & $0.23 \pm 0.03$ & $0.22 \pm 0.02$ & $0.450 \pm 0.02$ \\
\hline E24 & 0.001 & $7.5 \pm 3.3$ & $15.4 \pm 0.3$ & $2.8 \pm 0.3$ & $8 \pm 2$ & $0.175 \pm 0.005$ & $0.17 \pm 0.004$ & $0.275 \pm 0.002$ \\
\hline E35 & 0.01 & $19.1 \pm 0.4$ & $19.1 \pm 0.4$ & $7.3 \pm 0.3$ & $2 \pm 2$ & $0.25 \pm 0.006$ & $0.252 \pm 0.005$ & $0.500 \pm 0.004$ \\
\hline
\end{tabular}

Table 2: Model expressions for multiple burial and daylight exposure events normalized to 1 (Freisleben et al. $2015) ; x$ depth in rock $(\mathrm{mm}), \overline{\sigma \varphi_{\mathrm{o}}}$ is the trap-emptying rate at the surface $\left(\mathrm{s}^{-1}\right), \mu$ the light attenuation coefficient $\left(\mathrm{mm}^{-1}\right), \mathrm{t}_{\mathrm{e} 1}$ and $\mathrm{t}_{\mathrm{e} 2}$ are the first and second exposure period, $\mathrm{t}_{\mathrm{b} 1}$ the first burial periods, $\mathrm{D}(x)(\mathrm{Gy} / \mathrm{ka})$ is the dose rate at depth $x$ based on superposing principle in Aitken 1985, $\mathrm{D}_{0}(\mathrm{~Gy})$ is a sample dependent constant, characterizing the filling rate of the electron traps.

\begin{tabular}{lll}
\hline & \multicolumn{1}{c}{ Event } & $L(x)$ \\
\hline 0 & Burial long time & $\boldsymbol{L}_{0}(\boldsymbol{x})=\mathbf{1}$ \\
1 & First exposure & $\boldsymbol{L}_{1}(\boldsymbol{x})=\mathbf{L}_{0} \mathbf{e}^{-\overline{\boldsymbol{\sigma} \varphi_{0}} \mathbf{t}_{\mathrm{e} 1} e^{-\mu x}}$ \\
2 & First burial & $\boldsymbol{L}_{2}(\boldsymbol{x})=\left(\boldsymbol{L}_{1}(\boldsymbol{x})-\mathbf{1}\right) e^{-\boldsymbol{D}(\boldsymbol{x}) \boldsymbol{t}_{\mathrm{b} 1} / \boldsymbol{D}_{0}}+1$ \\
3 & Second exposure & $\boldsymbol{L}_{3}(\boldsymbol{x})=\boldsymbol{L}_{2}(\boldsymbol{x}) \mathbf{e}^{-\overline{\boldsymbol{\sigma} \varphi_{0}} \mathbf{t}_{\mathrm{e} 2} e^{-\mu x}}$ \\
\hline
\end{tabular}

Table 3: The fitting parametres for the three rock after applying equation $\mathrm{L}_{2}(x)$ for rock E02 and E35 and equation $\mathrm{L}_{3}(x)$ for rock $\mathrm{E} 24$.

\begin{tabular}{|l|l|l|l|l|}
\hline \multirow{2}{*}{ Surface } & \multirow{2}{*}{ Parameter } & \multicolumn{2}{l}{ Value from fitting } \\
\cline { 3 - 5 } & & Rock E02 & \multirow{2}{l}{ Rock E24 } & \multirow{2}{*}{ Rock E35 } \\
\hline \multirow{4}{*}{ Top (Inward for Rock E24) } & $\overline{\sigma \varphi_{0}} t_{e 1}$ & $9.3 \pm 2.5$ & $44.01 \pm 3.32$ & $99.6 \pm 40.8$ \\
\cline { 2 - 5 } & $\mu\left(m^{-1}\right)$ & $0.49 \pm 0.06$ & $0.32 \pm 0.02$ & $0.97 \pm 0.09$ \\
\cline { 2 - 5 } & $t_{b 1} / D_{o}\left(k a y^{-1}\right)$ & $0.22 \pm 0.02$ & $0.174 \pm 0.008$ & $0.20 \pm 0.01$ \\
\cline { 2 - 5 } & $\overline{\sigma \varphi_{0}} t_{e}$ & ------- & $5.0 \pm 0.18$ & ------- \\
\hline \multirow{3}{*}{ Bottom (Outward for Rock E24) } & $\overline{\sigma \varphi_{0}} t_{e 1}$ & $1.7 \pm 0.7$ & $1236.6 \pm 488.3$ & $2571 \pm 1751$ \\
\cline { 2 - 5 } & $\mu\left(m m^{-1}\right)$ & $0.49 \pm 0.06$ & $0.32 \pm 0.02$ & $0.97 \pm 0.09$ \\
\cline { 2 - 5 } & $t_{b 1} / D_{o}$ & $9 \times 10^{-18} \pm 0.2$ & $0.148 \pm 0.004$ & $0.24 \pm 0.01$ \\
\hline
\end{tabular}


Table 4: Dose rates, doses and ages at different depths of the three rocks. $L_{1}, L_{2}$ and $L_{3}$ are the predicted luminescence signals during the events $t_{\mathrm{e} 1}, \mathrm{t}_{\mathrm{b} 1}$ and $\mathrm{t}_{\mathrm{e} 2}$ respectively caculated using the fitted parameters values. Gray rows are for layers that were considered well bleached (pre-burial signal $<3 \%$ of the signal developed because of burial, see sextion 6).

*Depths are correceted to slice midpoint.

**The core layers where level of luminescence signals are in saturation, are not shown in the table 
Table 5: Burial ages using the value of the fitting parameter $\left(t_{b 1} / D_{o}\right)$ and direct ages from $D_{e}$ estimate derived from direct SAR measurements (given uncertainties are the total for random and 0.05 systematic uncertainties arising from external gamma dose rates calculated using gamma spectrometry, instrumental uncertainty for Ris $\varnothing$ OSL reader, beta source calibration $( \pm 2 \%)$ and water content $( \pm 2 \%))$.

\begin{tabular}{|c|c|c|c|c|c|}
\hline \multirow[t]{2}{*}{ Rock } & \multirow{2}{*}{$\begin{array}{l}\mathrm{D}_{0}, \mathrm{~Gy} \\
\text { (Dose } \\
\text { response } \\
\text { curve) }\end{array}$} & \multicolumn{2}{|c|}{$\begin{array}{l}\text { Burial age, ka } \\
\text { Using fitting parameter } t_{b 1} / D_{o}\end{array}$} & \multicolumn{2}{|c|}{$\begin{array}{l}\text { Burial age, ka } \\
\text { Using } D_{e} \text { estimates for well bleached slices (n; } \\
\text { number of well bleached sliceces) }\end{array}$} \\
\hline & & $\begin{array}{l}\text { Top } \\
\text { (inward for Rock E24) }\end{array}$ & $\begin{array}{l}\text { Bottom } \\
\text { (outward for Rock E24) }\end{array}$ & $\begin{array}{l}\text { Top } \\
\text { (inward for Rock E24) }\end{array}$ & $\begin{array}{l}\text { Bottom } \\
\text { (outward for Rock E24) }\end{array}$ \\
\hline E02 & $45.9 \pm 1.8$ & $10.098 \pm 0.998$ & --------- & $9.1 \pm 0.7(n=2)$ & --------- \\
\hline E24 & $51.4 \pm 2.4$ & $8.9 \pm 0.6$ & $7.6 \pm 0.4$ & $9.7 \pm 1.2(\mathrm{n}=2)$ & $8.6 \pm 0.7(n=15)$ \\
\hline E35 & $43.8 \pm 1.6$ & $8.8 \pm 0.5$ & $10.5 \pm 0.6$ & $10.48 \pm 1.09(\mathrm{n}=3)$ & $12.6 \pm 0.9(n=6)$ \\
\hline
\end{tabular}


Fig.1: Kite structures, Jibal al-Gadiwiyt kite in the southeast Jordan (provided by Tarawneh and Abu-Azezih) inset; outline map of Jordan and surrounding areas showing the distribution of known kites.

Fig.2: Trench 1 in Jibal al-Gadiwiyt (JGHD02) kite. (a) a top view for the open pit showing also the arm of the enclosure extending from pit. (b) Rock sample E24 from the wall construction. (c) Rock sample E02 and E35

Fig.3: Simplified cross section of the pit showing sample rocks and sediment samples for dose rate measurement.

Fig.4: Representative dose response curves and (inset) a typical stimulation curve compared to a normalized stimulation curve from calibration quartz for rock samples (a) E24 and (b) E35.

Fig.5: (a) Ratios of measured to given dose after blue light stimulation at room temperature and storage for 10ks for rock sample E24. (b) Dose recovery results at different preheat temperatures for the three rock samples

Fig.6: Luminescence-depth profiles for the three rocks fitted using equations $\mathrm{L}_{\mathrm{x} 2}$ and $\mathrm{L}_{\mathrm{x} 3}$

a) Rock E02; depth=0 $\mathrm{mm}$ is the top surface. black solid line is the result of fitting the data. Dashed blue line is the predicted profile shape after daylight exposure, before burial. $\sim 4$ full length cores were used to estimate $\mathrm{L}_{\mathrm{n}} / \mathrm{T}_{\mathrm{n}}, 8-12$ aliquots measured from each core for each $\mathrm{mm}$ depth.

(b) Rock E24; depth=0 $\mathrm{mm}$ is the inward surface. black solid line is the result of fitting the data. Blue Dashed line - after first daylight exposure before burial; red dot-dashed line - after first burial, before excavation. $\sim 5$ full length cores were used to estimate $\mathrm{L}_{\mathrm{n}} / \mathrm{T}_{\mathrm{n}}, 8-12$ aliquots measured from each core for each mm depth.

(c) Rock E35; depth=0 $\mathrm{mm}$ is the top surface. Black solid line is the result of fitting the data. Dashed blue line after daylight exposure, before burial. $\sim 4$ full length cores were used to estimate $\mathrm{L}_{\mathrm{n}} / \mathrm{T}_{\mathrm{n}}, 8-12$ aliquots measured from each core for each mm depth. 
Abu-Azizeh, W., \& Tarawneh, M. (2015). Out of the Harra: Desert Kites in Southeastern Jordan. New Results from the South Eastern Badia Archaeological Project. Arabian Archaeology and Epigraphy, 26(2), 95-119.

Abu-Azizeh, W. (2013). THE SOUTH-EASTERN JORDAN'S CHALCOLITHIC-EARLY BRONZE AGE PASTORAL NOMADIC COMPLEX: PATTERNS OF MOBILITY AND INTERACTION. Paléorient, 39(1), 149-176.

Aitken, M. J. (1985). Thermoluminescence dating . London: Academic Press.

al Khasawneh, S., Murray, A., \& Abudanah, F. (2018). A First Radiometric Chronology for the Khatt Shebib Megalithic Structure in Jordan using the Luminescence Dating of Rock Surfaces. Quaternary Geochronology, in press.

al Khasawneh, S., Murray, A., \& Abudanah, F. (Accepted- 2018). A First Radiometric Chronology for the Khatt Shebib Megalithic Structure in Jordan using the Luminescence Dating of Rock Surfaces. Quaternary Geochronology.

Bøtter-Jensen , L., Andersen , C., Duller , G., \& Murray, A. (2003). Developments in radiation, stimulation and observation facilities in luminescence measurements. Radiation Measurements, 37, 535-541.

Barge, O., \& Brochier, J. (2011). Visible from space, understood during the fieldwork: the example of "desert kites" in Armenia. Conference on cultural heritage and new technologies.

Bar-Oz, G., \& Nadel, D. (2013). Worldwide large-scale trapping and hunting of ungulates in past societies. Quaternary International, 297, 1-7.

Bar-Oz, G., Melinda , Z., \& Hole, F. (2011). Role of mass-kill hunting strategies in the extirpation of Persian gazelle (Gazella subgutturosa) in the northern Levant.". Proceedings of the National Academy of Sciences, 108(18), 7345-7350.

Betts, A. (1998). The Harra and the Hamad, Excavations and Survey in Eastern Jordan. Archaeological Monographs. Sheffield: Sheffield Academic Press.

Betts, A., \& Helms, S. (1987). The Desert "Kites" of the Badiyat Esh-Sham and North Arabia. 13(1), 41-67.

Burckhardt, J. (1831). Notes on the Bedouins and Wahabys, collected during his travels in the east. London: Colburn and Bently.

Fowden,, G. (1999). Desert kites': ethnography, archaeology and art. In H. Humphrey,, The Roman and Byzantine Near East: Some Recent Archaeological Research (Vol. 31, pp. 107-136). Journal of Roman Archaeology: Supplementary Series.

Freisleben, T., Sohbati, R., Murray, A., Jain, M., al Khasawneh, S., Hvidt, S., \& Jakobsen, B. (2015). Mathematical model quantifies multiple daylight exposure and burial events for rock surfaces using luminescence dating. Radiation Measurements, in press.

Guérin, G., Mercier, N., \& Adamiec, G. (2011). Dose-rate conversion factors: update. Ancient TL , 29(1), 5-8.

Hansen, V., Murray, A., Buylaert, J., Yeoa, E., \& Thomsen, K. (2015). A new irradiated quartz for beta source calibration. Radiation Measurements, 81, 123-127.

Harding, G. (1953). The cairn of Hani. Annual of the Department of Antiquities of Jordan, 2, 8-56. 
Holzer, A., Avner , U., Porat, N., \& Kolska Horwitz, L. (2010). Desert kites in the Negev desert and northeast Sinai: Their function, chronology and ecology. Journal of Arid Environments, xxx, 1-12.

Hoyland, R. (2001). Arabia and the Arabs: from the Bronze Age to the coming of Islam. London: Routledge.

Kempe, S., \& Al- Malabeh, A. (2010). Kites and other Archaeological Structures along the Eastern Rim of the Harrat (Lava Plain) of Jordan, Signs of Intensive Usage in Prehistoric Time, a Google Earth Images Study. Proceedings 14th International Symposium on Vulcanospeleology, 199-216.

Kempe, S., \& Al-Malabeh, A. (2012). Distribution, Sizes, Function and Heritage Importance of the Harrat Al Shaam Desert Kites: The Largest Prehistoric Stoneworks of Mankind? 15TH INTERNATIONAL SYMPOSIUM ON VUCANOSPELEOLOGY , 57-66.

Kennedy, D., \& Bishop, M. (2011). Google Earth and the archaeology of Saudi Arabia. A case study from the Jeddah area. Journal of Archaeological Science, 38(6), 1284-1293.

MacDonald, M. (2005). Of Rock-art, 'Desert Kites' and Mesayid. In A. Sedov, \& I. Smulyanskaya (Eds.), Arabia Vitalis: Arabskij Vostok, Islam, drevnyaya, Araviya: Sbornik Naychnykh statej, posvyashchennyj 60-letiyu V.V. Naumkina (pp. 332-345). Moscow: Rossijskaya Akademiya Nauk.

Maitland, R. (1927). The 'works of the old man' in Arabia. Antiquity,, 1, 197-203.

Murray, A. S., \& Wintle, A. G. (2000). Luminescence dating of quartz using an improved single-aliquot regenerative-dose protocol. . Radiation Measurements, 32, 57-73.

Murray, A., \& Wintle, A. (2003). The single aliquot regenerative dose protocol: Potential for improvements in reliability. Radiation Measurements, 37, 377-381.

Murray, A., Marten, R., Johnston, A., \& Martin, P. (1987). Analysis for naturally occuring radionuclides at environmental concentrations by gamma spectrometry. Journal of Radioanalytical and Nuclear Chemistry, 115(2), 263-288.

Musil, A. (1928). The manners and customs of the Rwala Bedouins. In Oriental Explorations and Studies (Vol. 6). New York: American Geographical Society.

Prescott, J. R., \& Hutton, J. T. (1994). Cosmic ray contributions to dose rates for luminescence and ESR dating: large depths and long-term variations. Radiation Measurements, 23, 497-500.

Rees, L. (1929). The Transjordan desert. Antiquity, 3(12), 389-407.

Sohbati , R., Murray , A., Jain , M., Buylaert , J., \& Thomsen, K. (2011). Investigating the resetting of OSL signals in rock surfaces. Geochronometria, 38, 249-258.

Sohbati, R., Murray, A., Porat, N., Mayank, J., \& Avner, U. (2015). Age of a prehistoric "Rodedian" cult site constrained by sediment and rock surface luminescence dating techniques. Quaternary Geochronology, 30, 90-99.

Thomsen , K., Jain , M., Bøtter-Jensen , L., \& Murray , A. (2003). Variation with depth of dose distributions of single grains of quartz extracted from an irradiated concrete block. Radiation Measurements, $37,315-321$.

Thomsen, K., Murray, A., Bøtter-Jensen, L., \& Kinahan, J. (2007). Determination of burial dose in incompletely bleached fluvial samples using single grains of quartz. Radiation Measurements, 42(3), 370-379. 
van Berg, P., Vander Linden, M., Picalause, V., Lemaitre , S., \& Cauwe, N. (2004). Desert-kites of the Hemma plateau (Hassake, Syria). Paléorient, 89-99.

Wright, W. (1895). An account of Palmyra and Zenobia with travels and adventures in Bashan and the desert. London: T. Nelson Edition.

Zeder, M., Bar-Oz, G., Rufolo, S., \& Hole, F. (2013). New perspectives on the use of kites in mass-kills of Levantine gazelle: a view from northeastern Syria. Quaternary International, 297, 110-125. 
Animal traps (hides)

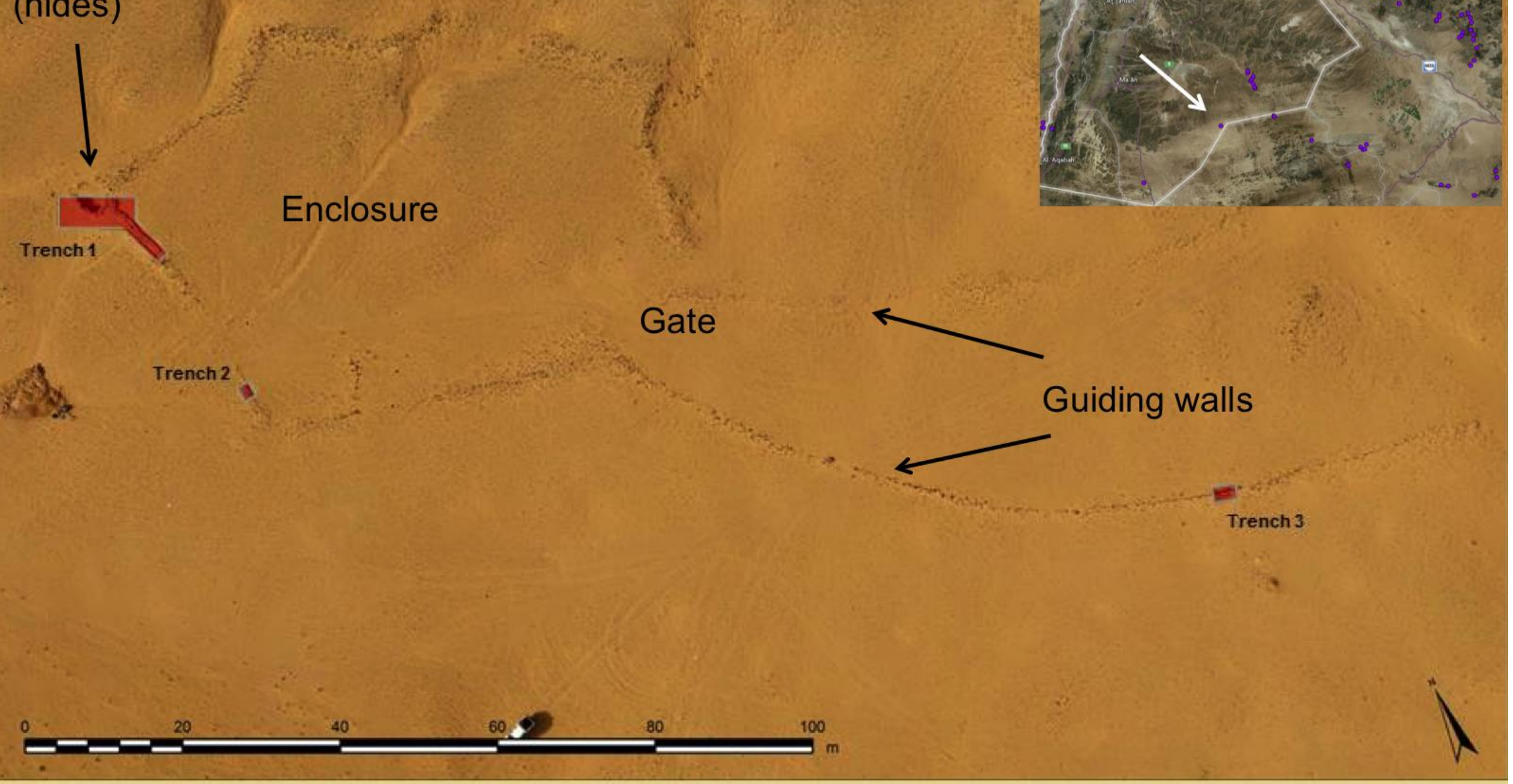

Figure 1: Kite structures, Jibal al-Gadiwiyt kite in the southeast Jordan (provided by Tarawneh and Abu-Azezih, personal communication. inset; outline map of Jordan and surrounding areas showing the distribution of known kites.). 
(a)

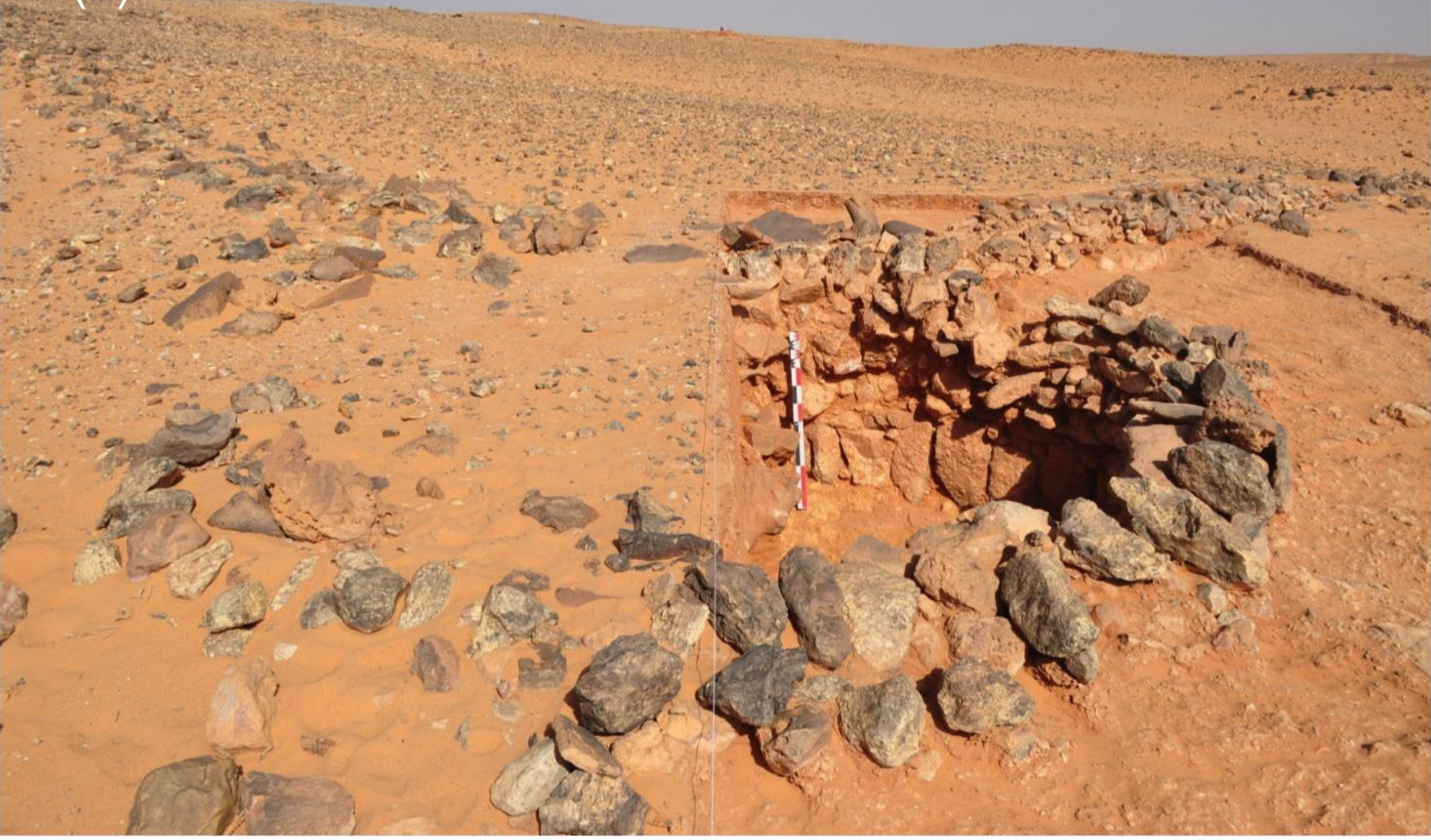

Figure 2: Trench 1 in Jibal al-Gadiwiyt (JGHD02) kite. (a) a top view for the open pit showing also the arm of the enclosure extending from pit. (b) Rock sample E24 from he wall construction. (c) Rock sample E02 and E35 


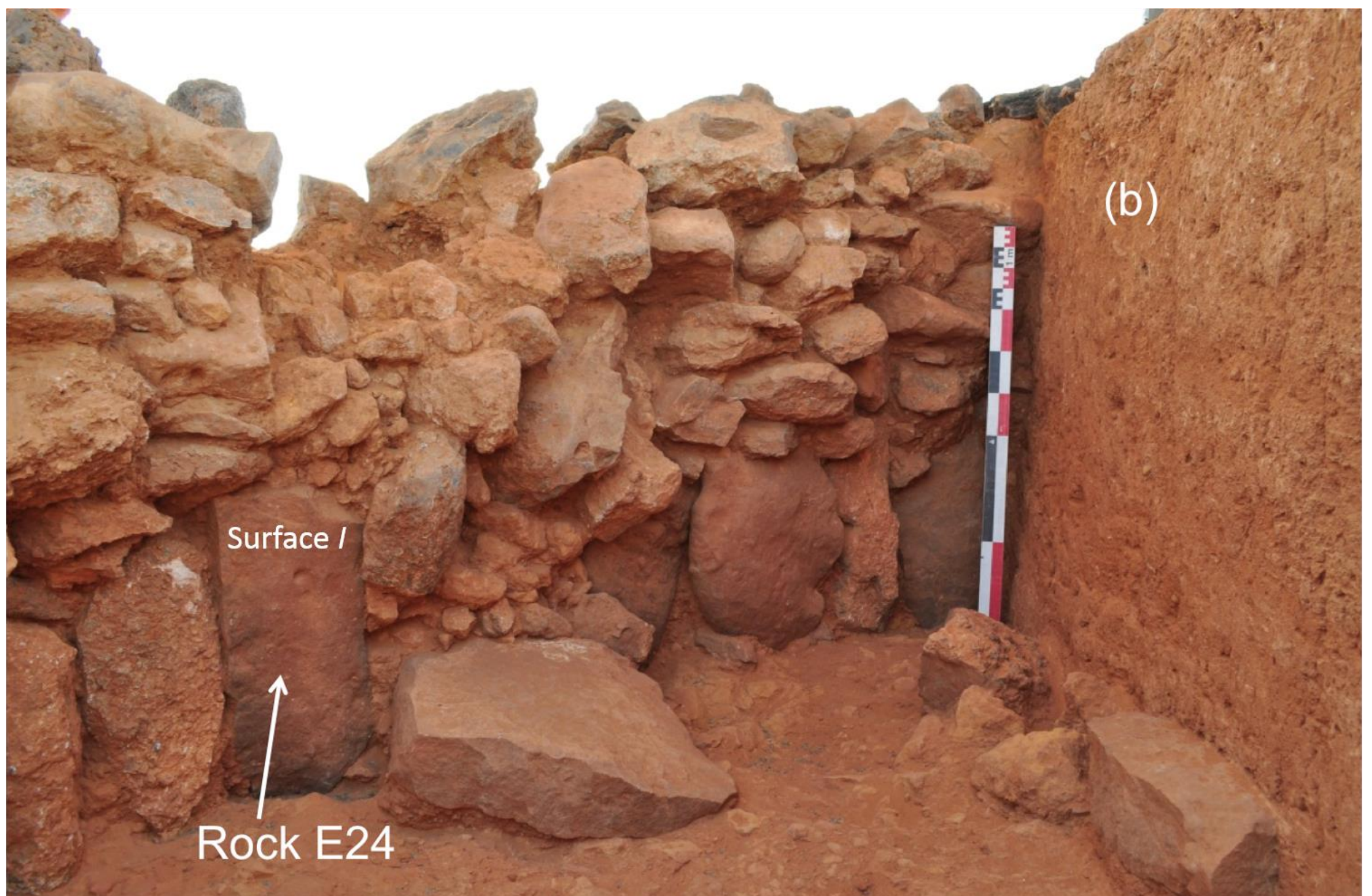

Figure 2: Trench 1 in Jibal al-Gadiwiyt (JGHD02) kite. (a) a top view for the open pit showing also the arm of the enclosure extending from pit. (b) Rock sample E24 from he wall construction. (c) Rock sample E02 and E35 
(c) 
Figure 3: Simplified cross section of the pit showing sample rocks and sediment samples for dose rate measurement. WEST

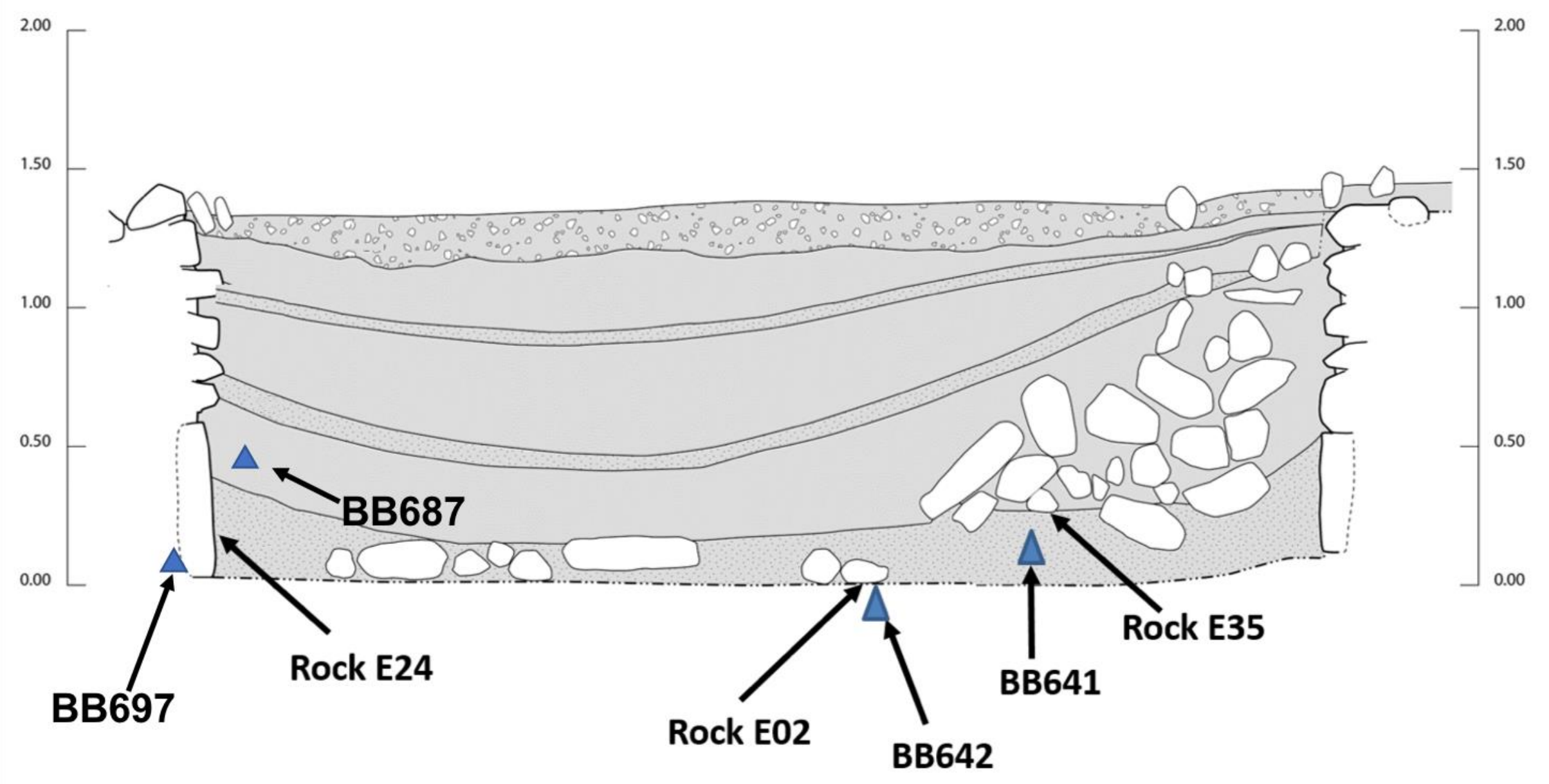




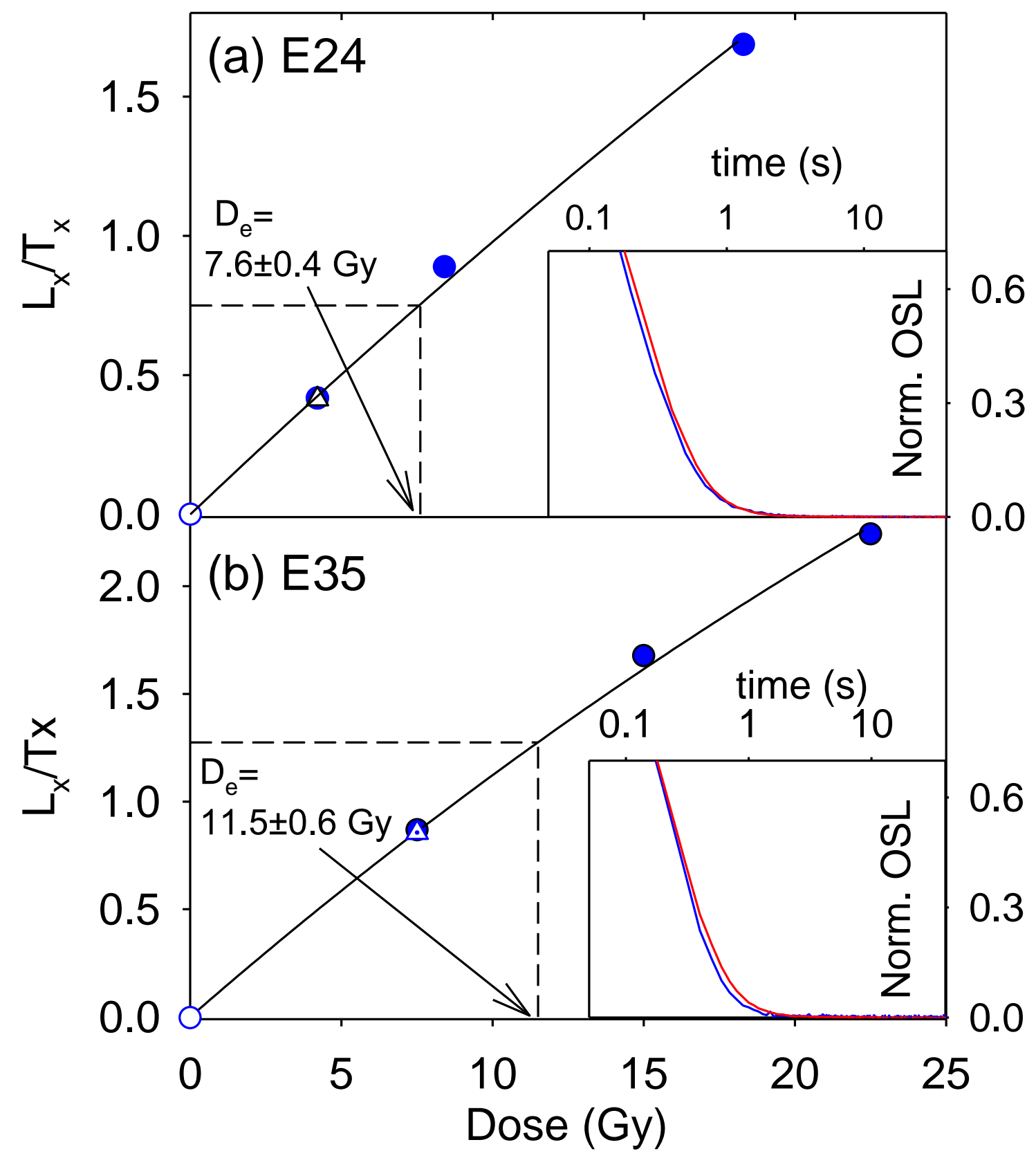

Figure 4: representative dose response curves and (inset) a typical stimulation curve compared to a normalized stimulation curve from calibration quartz for rock samples (a) E24 and (b) E35. 


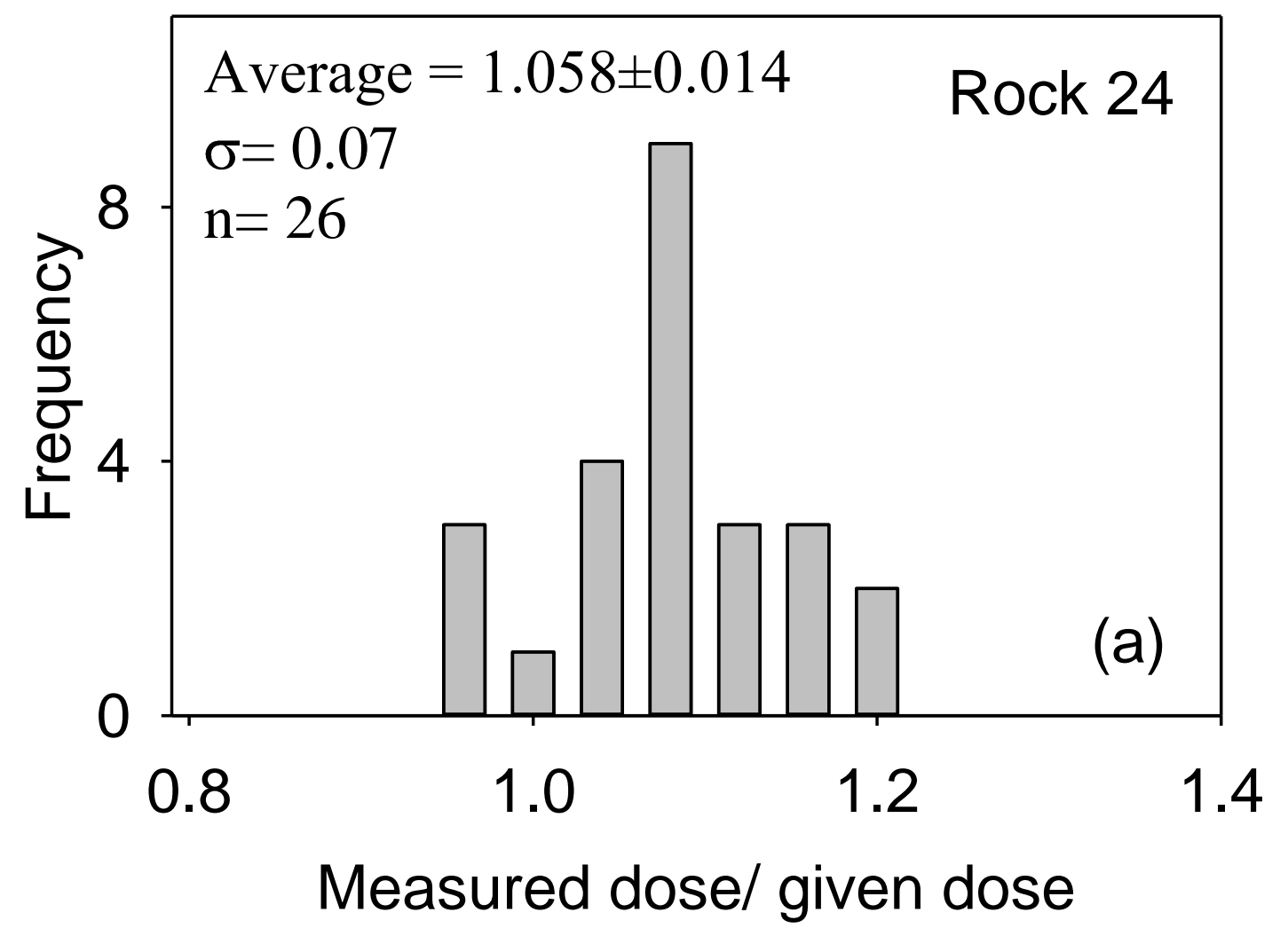

Figure 5: (a) Ratios of measured to given dose after blue light stimulation at room temperature and storage for $10 \mathrm{ks}$ for rock sample E24. (b) Dose recovery results at different preheat temperatures for the three rock samples. 


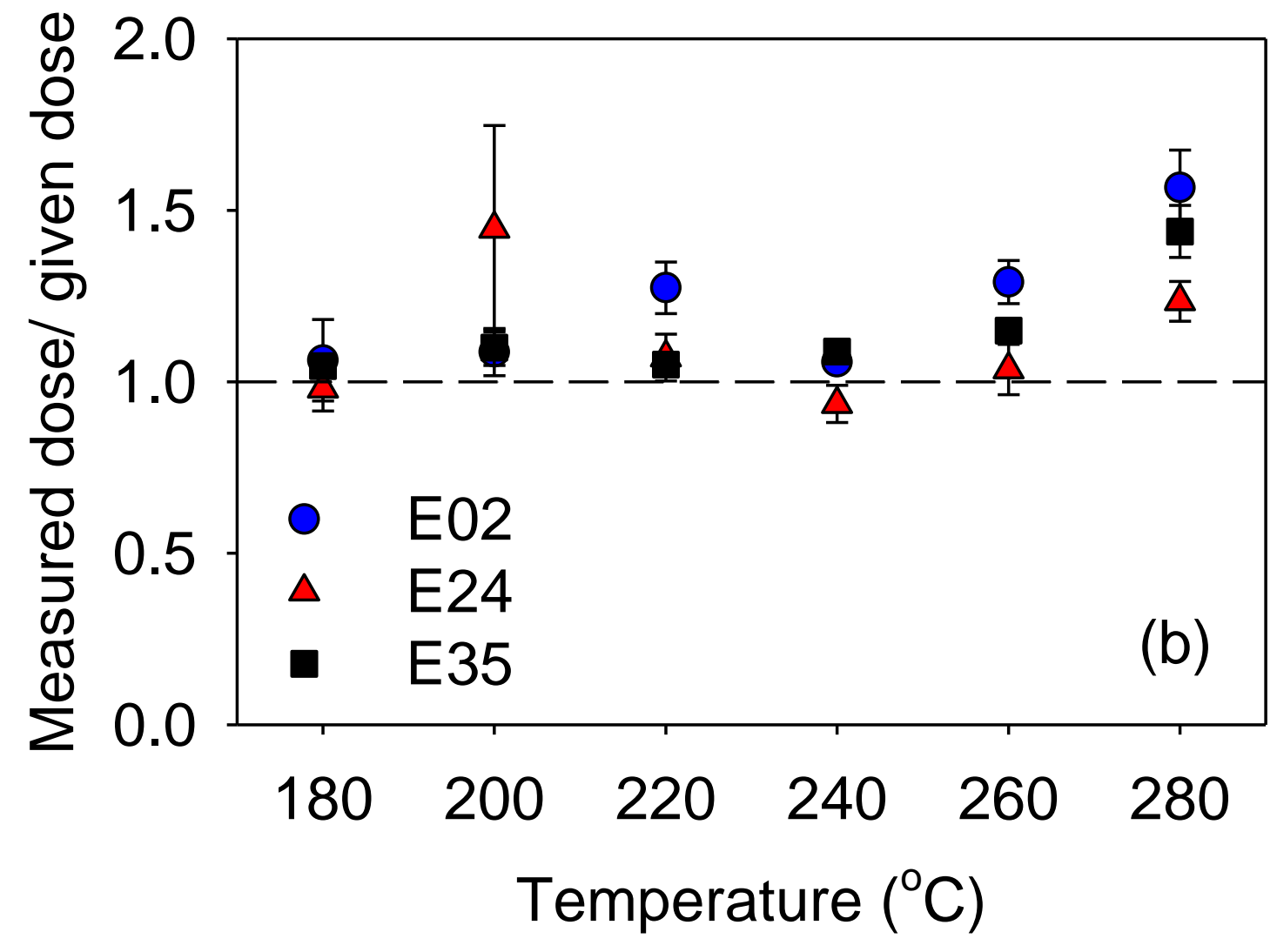




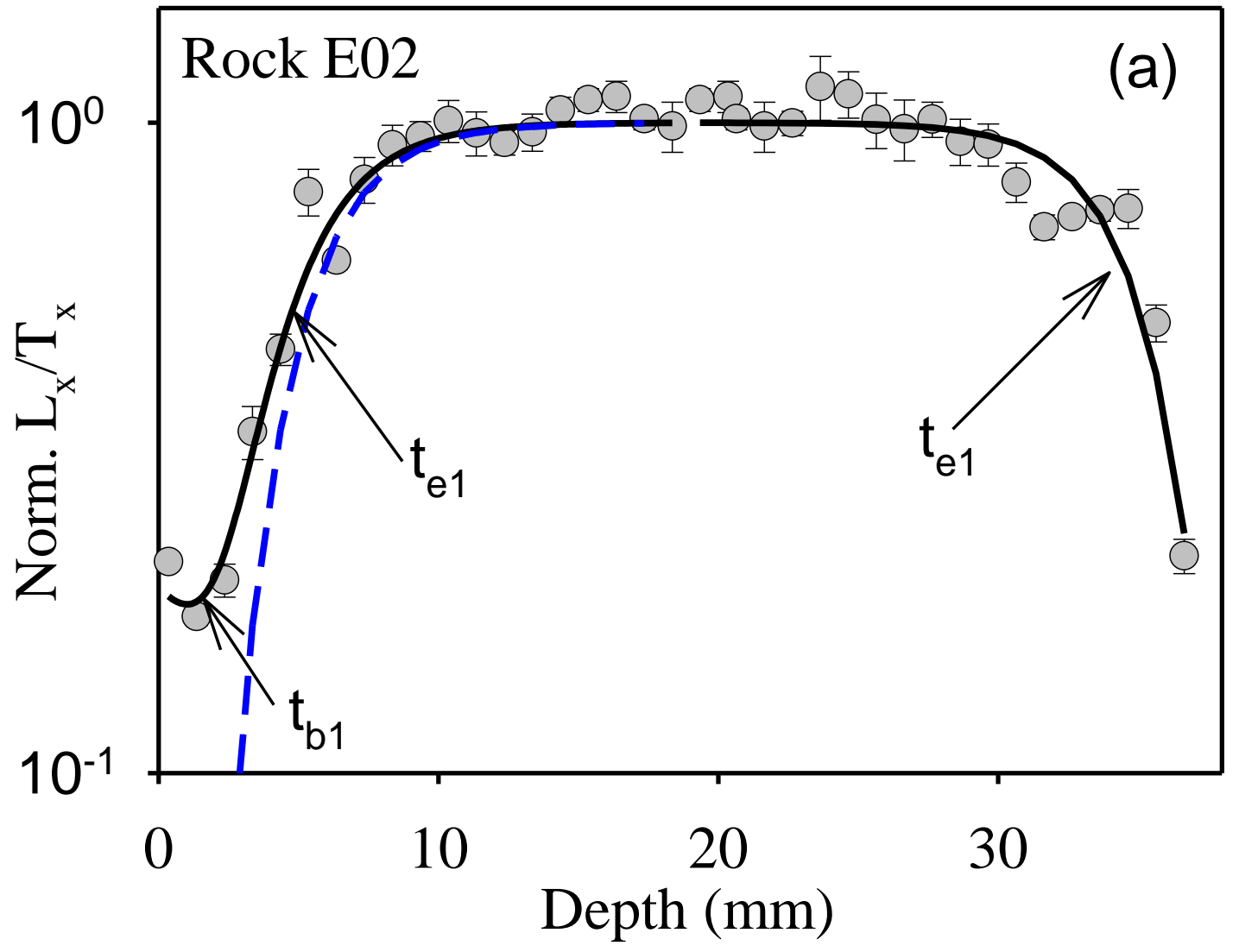

Fig.6: Luminescence-depth profiles for the three rocks fitted using equations $\mathrm{L}_{\mathrm{x} 2}$ and $\mathrm{L}_{\mathrm{x} 3}$

a) Rock E02; depth=0 $\mathrm{mm}$ is the top surface. black solid line is the result of fitting the data. Dashed blue line is the predicted profile shape after daylight exposure, before burial. 4 full length cores were used to estimate $\mathrm{L}_{\mathrm{n}} / \mathrm{T}_{\mathrm{n}}, 8-12$ aliquots measured from each core for each mm depth.

(b) Rock E24; depth=0 $\mathrm{mm}$ is the inward surface. black solid line is the result of fitting the data. Blue Dashed line - after first daylight exposure before burial; red dotdashed line - after first burial, before excavation. $\sim 5$ full length cores were used to estimate $\mathrm{L}_{\mathrm{n}} / \mathrm{T}_{\mathrm{n}}, 8-12$ aliquots measured from each core for each mm depth.

(c) Rock E35; depth $=0 \mathrm{~mm}$ is the top surface. Black solid line is the result of fitting the data. Dashed blue line - after daylight exposure, before burial. $\sim 4$ full length cores were used to estimate $\mathrm{L}_{\mathrm{n}} / \mathrm{T}_{\mathrm{n}}, 8-12$ aliquots measured from each core for each mm depth. 


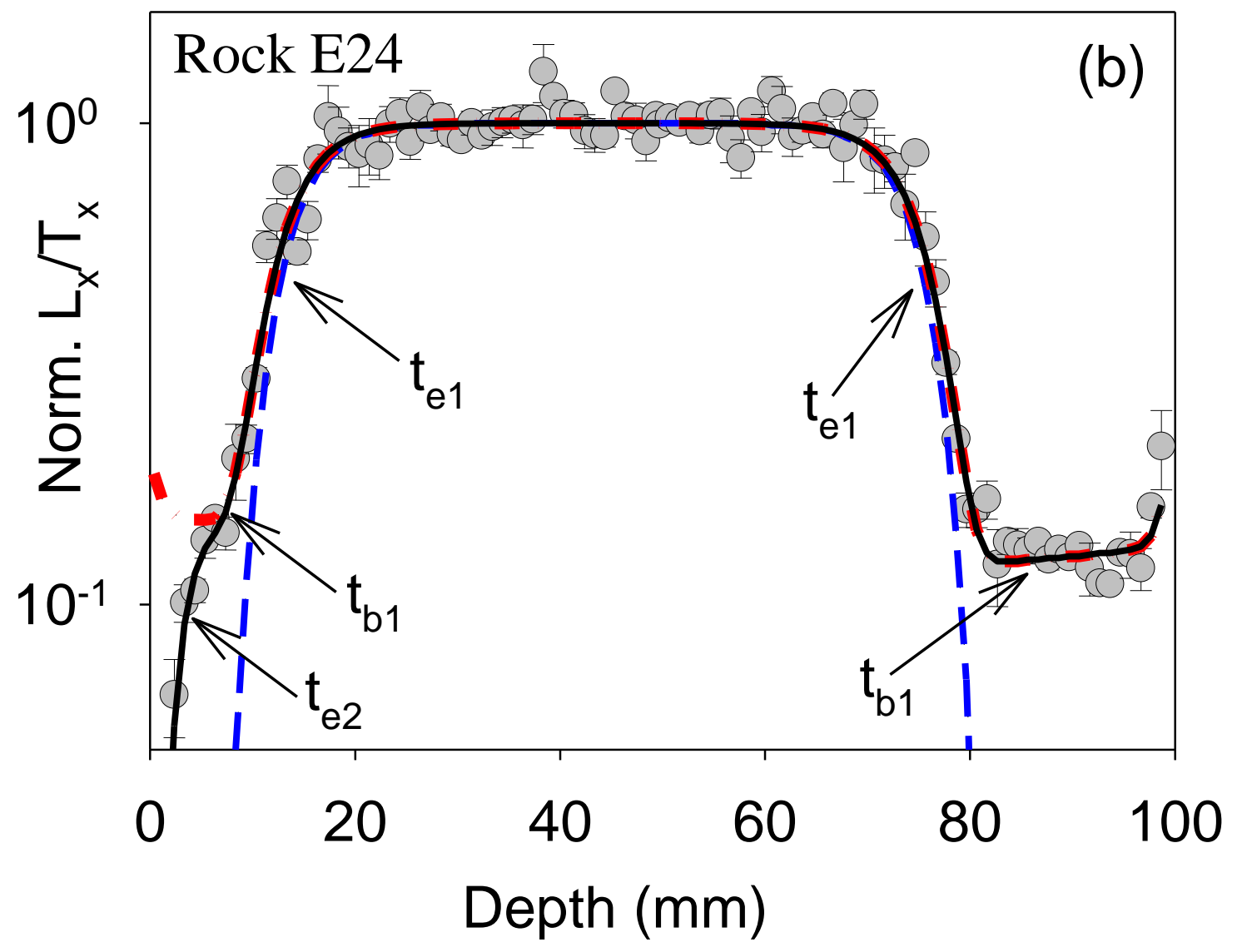

Fig.6: Luminescence-depth profiles for the three rocks fitted using equations $\mathrm{L}_{\mathrm{x} 2}$ and $\mathrm{L}_{\mathrm{x} 3}$

a) Rock E02; depth=0 $\mathrm{mm}$ is the top surface. black solid line is the result of fitting the data. Dashed blue line is the predicted profile shape after daylight exposure, before burial. 4 full length cores were used to estimate $\mathrm{L}_{\mathrm{n}} / \mathrm{T}_{\mathrm{n}}, 8-12$ aliquots measured from each core for each mm depth.

(b) Rock E24; depth=0 $\mathrm{mm}$ is the inward surface. black solid line is the result of fitting the data. Blue Dashed line - after first daylight exposure before burial; red dotdashed line - after first burial, before excavation. $\sim 5$ full length cores were used to estimate $\mathrm{L}_{\mathrm{n}} / \mathrm{T}_{\mathrm{n}}, 8-12$ aliquots measured from each core for each mm depth.

(c) Rock E35; depth=0 $\mathrm{mm}$ is the top surface. Black solid line is the result of fitting the data. Dashed blue line - after daylight exposure, before burial. 4 full length cores were used to estimate $\mathrm{L}_{\mathrm{n}} / \mathrm{T}_{\mathrm{n}}, 8-12$ aliquots measured from each core for each mm depth. 


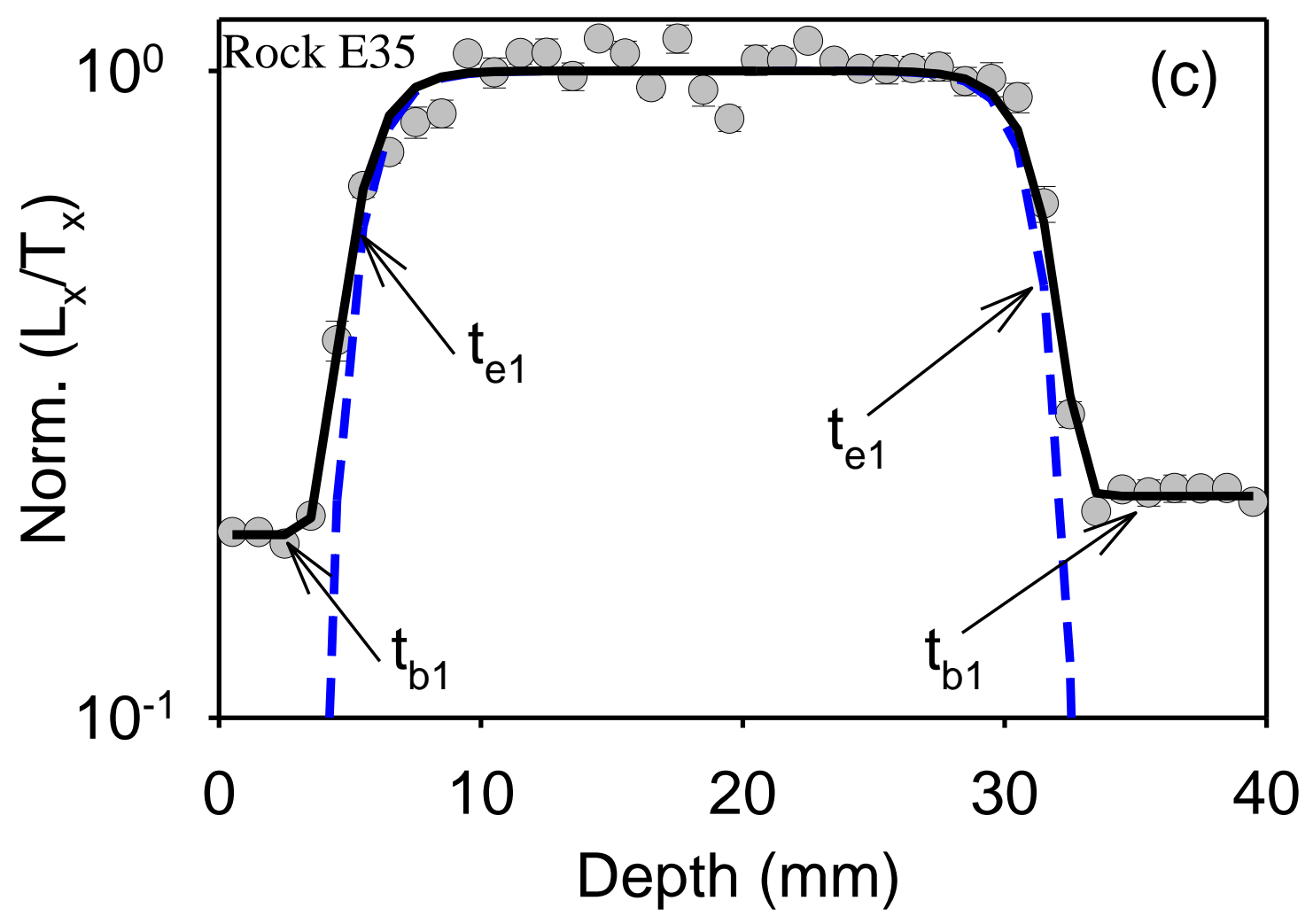

Fig.6: Luminescence-depth profiles for the three rocks fitted using equations $\mathrm{L}_{\mathrm{x} 2}$ and $\mathrm{L}_{\mathrm{x} 3}$

a) Rock E02; depth $=0 \mathrm{~mm}$ is the top surface. black solid line is the result of fitting the data. Dashed blue line is the predicted profile shape after daylight exposure, before burial. $\sim 4$ full length cores were used to estimate $\mathrm{L}_{\mathrm{n}} / \mathrm{T}_{\mathrm{n}}, 8-12$ aliquots measured from each core for each mm depth.

(b) Rock E24; depth=0 $\mathrm{mm}$ is the inward surface. black solid line is the result of fitting the data. Blue Dashed line - after first daylight exposure before burial; red dotdashed line - after first burial, before excavation. $\sim 5$ full length cores were used to estimate $\mathrm{L}_{\mathrm{n}} / \mathrm{T}_{\mathrm{n}}, 8-12$ aliquots measured from each core for each mm depth.

(c) Rock E35; depth=0 $\mathrm{mm}$ is the top surface. Black solid line is the result of fitting the data. Dashed blue line - after daylight exposure, before burial. 4 full length cores were used to estimate $\mathrm{L}_{\mathrm{n}} / \mathrm{T}_{\mathrm{n}}, 8-12$ aliquots measured from each core for each mm depth. 